\title{
Topiramate has protective effect on renal injury
}

\author{
Cure $\mathrm{MC}^{1}$, Cure $\mathrm{E}^{2}$, Tumkaya $\mathrm{L}^{3}$, Kalkan $\mathrm{Y}^{3}$, Aydin $\mathrm{I}^{4}$, Kirbas $\mathrm{A}^{1}$, Efe $\mathrm{H}^{1}$, Sehitoglu $\mathrm{I}^{5}$, Yuce $\mathrm{S}^{2}$ \\ Recep Tayyip Erdogan University, School of Medicine, Department of Biochemistry, Rize, Turkey. \\ medinecure@yahoo.com
}

\begin{abstract}
Background: Topiramate (TPM) decreases tumor necrosis factor-alpha (TNF- $\alpha$ ) and oxidative stress. We investigated protective effects of TPM on cell damage in kidney tissue during ischemia-reperfusion (I/R) damage. Methods: A total of 30 male Wistar albino rats were divided into three groups: control, I/R, and I/R plus TPM (I/ R+TPM). Laparotomy without I/R injury was performed in control group. After laparotomy, cross ligation of infrarenal abdominal aorta was applied for two hours in I/R groups which was followed by two hours of reperfusion. TPM $(100 \mathrm{mg} / \mathrm{kg} /$ day) was orally administrated to animals in the I/R+TPM group for seven consecutive days before I/R. Results: The I/R group's TNF- $\alpha$ and interleukin-1 beta (IL-1 $\beta$ ) levels were significantly higher (1184.2 \pm 129.1 $\mathrm{pg} / \mathrm{mg}$ protein; $413.1 \pm 28.8 \mathrm{pg} / \mathrm{mg}$ protein, respectively) than those of the control $(907.8 \pm 113.0 \mathrm{pg} / \mathrm{mg}$ protein, $p=0.002 ; 374.7 \pm 23.7 \mathrm{pg} / \mathrm{mg}$ protein, $\mathrm{p}=0.010$, respectively) and $\mathrm{l} / \mathrm{R}+\mathrm{TPM}$ groups (999.5 $\pm 115.2 \mathrm{pg} /$ $\mathrm{mg}$ protein, $\mathrm{p}<0.001 ; 377.9 \pm 30.9 \mathrm{pg} / \mathrm{mg}$ protein, $\mathrm{p}=0.007$, respectively).

Conclusion: TPM may partially prevent renal damage in rats. The opening of new horizons of this kind of knowledge will help understand the complex challenge in the prevention of renal I/R damage (Tab. 1, Fig. 3, Ref. 42). Text in PDF www.elis.sk.

Key words: topiramate, ischemia reperfusion, kidney, carbonic anhydrase II.
\end{abstract}

\section{Introduction}

Renal ischemia/reperfusion (I/R) injury affects the prognosis of patients in a wide range of clinical situations including transplantation, renal resection surgery, abdominal trauma, and hemorrhagic shock and aorta injury during abdominal surgery (1). Aortic occlusion and reperfusion produce distant organ injury by multiple mechanisms including neutrophilic infiltration and the generation of reactive oxygen species (ROS) and cytokines (2, 3). As shown in the present findings, high activities of markers such as tumor necrosis factor-alpha (TNF- $\alpha$ ) and Interleukin-1 beta (IL-1 $\beta$ ) increase ischemic kidney tissue damage that occurs during I/R injury $(4,5)$. The release of the mediators TNF- $\alpha$ and IL- $1 \beta$ starts at the beginning of reperfusion and increases during the early phase of $\mathrm{I} / \mathrm{R}$ in kidney $(6,7)$. The surge of oxygen to low oxygenated tissues causes increased production of ROS by TNF- $\alpha$ and IL-1 $\beta$ (8). The apoptosis pathway is activated as a result of mitochondrial dam-

${ }^{1}$ Recep Tayyip Erdogan University, School of Medicine, Department of Biochemistry, Rize, Turkey, ${ }^{2}$ Recep Tayyip Erdogan University, School of Medicine, Department of Internal Medicine, Rize, Turkey, ${ }^{3}$ Recep Tayyip Erdogan University, School of Medicine, Department of Histology and Embryology, Rize, Turkey, ${ }^{4}$ Recep Tayyip Erdogan University, School of Medicine, Department of Surgery, Rize, Turkey, and ${ }^{5}$ Recep Tayyip Erdogan University, School of Medicine, Department of Pathology, Rize, Turkey Address for correspondence: MC Cure, Department of Biochemistry, University of Recep Tayyip Erdogan, School of Medicine, Rize, 53100, Turkey. Phone: +90.4642130491, Fax: +90.4642170364

Acknowledgement: The authors would like to thank Ayhan Kanat who improved the spelling errors in this article. Source of Support: RTEU Bilimsel Arastirmalar Proje birimi (BAP), Project number: 2012.106.01.8. age caused by ROS. Apoptosis plays also a major role in kidney injury induced by $\mathrm{I} / \mathrm{R}$.

Topiramate (TPM), which is a sulfamate-substituted monosaccharide, is used in neurotherapy for the management of epilepsy and migraine (9). It is documented to possess weight-reducing properties in addition to insulin resistance-improving effects $(10$, 11). It has been demonstrated that TPM decreases TNF- $\alpha$ and oxidative stress in addition to being an effective antioxidant $(11,12$, 13). The inhibition of TNF- $\alpha$ release or its neutralization with antiTNF- $\alpha$ antibodies decreases the number of neutrophils infiltrating the kidney and reduces I/R injury (14). Carbonic anhydrase (CA)II is a zinc metallo-enzyme that catalyzes the reversible hydration of $\mathrm{CO}_{2}$ to form carbonic acid $\left(\mathrm{H}_{2} \mathrm{CO}_{3}\right)$. CA-II has a wide tissue distribution, being found especially kidney (proximal tubules and collecting duct) (15). Previous study reported that TPM behaves as a very potent inhibitor of human CA-II (16). Another study showed that oxidative stress induced by diabetes has increased CA activity in the diabetic group more than in the control group (17).

The aim of this study was to investigate whether the inhibition of TNF- $\alpha$ and IL-1 $\beta$ by TPM ameliorates I/R-induced kidney tissue injury by suppressing cell apoptosis.

\section{Materials and methods}

\section{Animals}

Thirty Wistar albino male rats, weighing 250-300 g (12-15 weeks old), were used in the present study. The rats were randomly divided into three experimental groups: the control group $(n=10)$, the I/R group $(\mathrm{n}=10)$, and the I/R plus TPM $(\mathrm{I} / \mathrm{R}+\mathrm{TPM})$ group ( $=10$ ). This research was performed in accordance with the Guide 


\section{9-263}

for the Care and Use of Laboratory Animals, (NIH, 1985) and approved by the local ethical committee at the Recep Tayyip Erdogan University Medical School (Approval numbers: 2012/10).

\section{Experimental design}

Rats in the control groups received saline solution. Midline laparotomy and dissection of the infrarenal abdominal aorta (IAA) without occlusion was performed in the control group. However, laparotomy and clamping of the IAA for $120 \mathrm{~min}$, followed by $120 \mathrm{~min}$ of reperfusion was carried out in the I/R group. I/R+TPM groups, TPM $\left(100 \mathrm{mg} / \mathrm{kg} /\right.$ day, Topamax ${ }^{\circledR}$, Johnson\&Johnson) was orally (via gastric gavage) administered for seven consecutive days before I/R (18). At the end of seven days, $120 \mathrm{~min}$ of ischemia and $120 \mathrm{~min}$ of reperfusion was performed in the I/R+TPM group.

\section{Aortic I/R}

The I/R model was designed similarly to previous studies (2, 19). Male Wistar rats, were anesthetized intraperitoneally with ketamine hydrochloride (Ketalar, $50 \mathrm{mg} / \mathrm{kg}$ intramuscularly; Eczacibasi, Istanbul, Turkey), and placed supine on a heated mat. $10 \mathrm{ml}$ per hour of sterile saline was injected subcutaneously into the neck of the animals to replace surgical fluid losses from evaporation. A midline laparotomy was performed and a window dissected in the retroperitoneum to expose the infrarenal aorta. A microvascular clamp was placed across the IAA. The abdomen was closed, and the wound was covered with plastic wrap to minimize the loss of heat and fluid. After $120 \mathrm{~min}$, the microvascular clamp on the IAA was removed and the lower limb reperfusion was maintained for $120 \mathrm{~min}$. Aortic occlusion and reperfusion was confirmed by the loss and reappearance of the pulsation on the distal aorta. At the end of the reperfusion, a median sternotomy was performed and the blood samples were drawn from the right ventricles of all rats for biochemical analyses. All rats were killed, and their kidneys were removed meticulously.

\section{Biochemical parameters}

The blood samples $(10 \mathrm{~mL})$ were collected into tubes. The blood was separated by centrifugation at $3000 \mathrm{rpm}$ for $10 \mathrm{~min}$ after standing at room temperature for $15 \mathrm{~min}$. Biochemical parameters including urea and creatinine were determined from serum using the determined commercial kits (Architect c 16000, Abbott Laboratories, USA).

\section{Tissue homogenates}

The samples were homogenized in PBS, $\mathrm{pH} 7.4$, and centrifuged at $10,000 \mathrm{~g}$ for $20 \mathrm{~min}$. Aliquot of the supernatant was put into tubes and frozen at $-80{ }^{\circ} \mathrm{C}$. The parameters were checked within one month.

\section{Measurement of protein}

Tissue homogenate protein assay is a turbidimetric procedure in which benzethonium chloride is used as the protein denaturing agent. Proteins in the form of a fine suspension were quantitated turbidimetrically at $404 \mathrm{\eta m}$. (Architect c 16000, Abbott Laboratories, USA).
$T N F-\alpha$

The TNF- $\alpha$ concentration was measured using the enzymelinked immunosorbent assay (ELISA) method. We used the commercially available rat TNF- $\alpha$ ELISA kit (eBioscience, Vienna, Austria). When dividing the obtained values by protein levels, the final results were obtained as $\mathrm{pg} / \mathrm{mg}$ protein.

\section{$I L-1 \beta$}

The IL-1 $\beta$ concentration was also measured using the enzymelinked immunosorbent assay (ELISA) method. We used the commercially available rat IL-1 $\beta$ ELISA kit (eBioscience, Vienna, Austria). When dividing the obtained values by protein levels, the final results were obtained as $\mathrm{pg} / \mathrm{mg}$ protein.

\section{Immunohistological evaluation}

For immunohistochemical staining, 3-4 $\mu$ m-thick sections were cut and allowed to stand in xylene for 20 minutes before the application of the alcohol series (50-100\%) and then stand for $10 \mathrm{~min}$ in $\mathrm{H} 2 \mathrm{O} 2$ solution. After being washed by PBS they were heated in a citrate buffer solution by 800 Watt power for 4 $-5 \mathrm{~min}$ and then allowed to stand in a secondary blocker substance for $20 \mathrm{~min}$. Each slide standed for $75 \mathrm{~min}$ in different dilutions of primary antibody [TNF- $\alpha$ $1 \mu \mathrm{g} / \mathrm{ml}$ and for Carbonic anhydrase (CA) II 1/250-/500] before being stained by Anti-CA II (cod: ab124687, Abcamplc, Cambridge CB4 0FLUK), and Anti-TNF- $\alpha$ antibody (cod: ab66579, Abcamplc, Cambridge CB4 0FLUK). Diaminobenzidine solution was used as an achromogen and Mayer's hematoxylin was used as a counterstain for 3-5 min. PBS was used as a negative controller. Preparations were photographed after being covered with appropriate covering materials. As a result of immunohistochemical staining, preparations were divided into four categories according to the tissues' percentage of immunopositive reaction areas as mild $(+)$, moderate $(++)$, severe $(+++)$, and very severe $(++++)$. The blocked tissues were cut into $4-5 \mu \mathrm{m}$-thick sections before being stained by hematoxylin and eosin (H\&E) for histopathological examination, and then areas found appropriate for histopathological evaluation were photographed. Tissues were blindly evaluated by two histologists.

\section{Statistical analyses}

The results are presented as mean $\pm \mathrm{SD}$. The Kruskal-Wallis test was used to compare the groups. A Bonferroni adjusted MannWhitney $U$ test was used to compare the two groups. Statistically significant differences were obtained at a p value of less than 0.05 .

\section{Results}

\section{Biochemical parameters}

The I/R group's creatinine levels were significantly higher $(0.55 \pm 0.02 \mathrm{mg} / \mathrm{dl})$ than those of the control $(0.42 \pm 0.05 \mathrm{mg} / \mathrm{dl}$, $\mathrm{p}<0.001)$ and $\mathrm{I} / \mathrm{R}+\mathrm{TPM}$ groups $(0.49 \pm 0.03 \mathrm{mg} / \mathrm{dl}, \mathrm{p}<0.001)$. The I/R group's urea levels were significantly higher $(60.0 \pm 17.4$ $\mathrm{mg} / \mathrm{dl})$ than those of the control $(39.8 \pm 4.6 \mathrm{mg} / \mathrm{dl}, \mathrm{p}=0.004)$. The $\mathrm{I} / \mathrm{R}$ group's TNF- $\alpha$ levels $(1184.2 \pm 129.1 \mathrm{pg} / \mathrm{mg}$ protein $)$ were significantly higher than those of the control $(907.8 \pm 113.0 \mathrm{pg} /$ $\mathrm{mg}$ protein, $\mathrm{p}=0.002)$ and $\mathrm{I} / \mathrm{R}+\mathrm{TPM}$ groups $(999.5 \pm 115.2 \mathrm{pg} /$ 

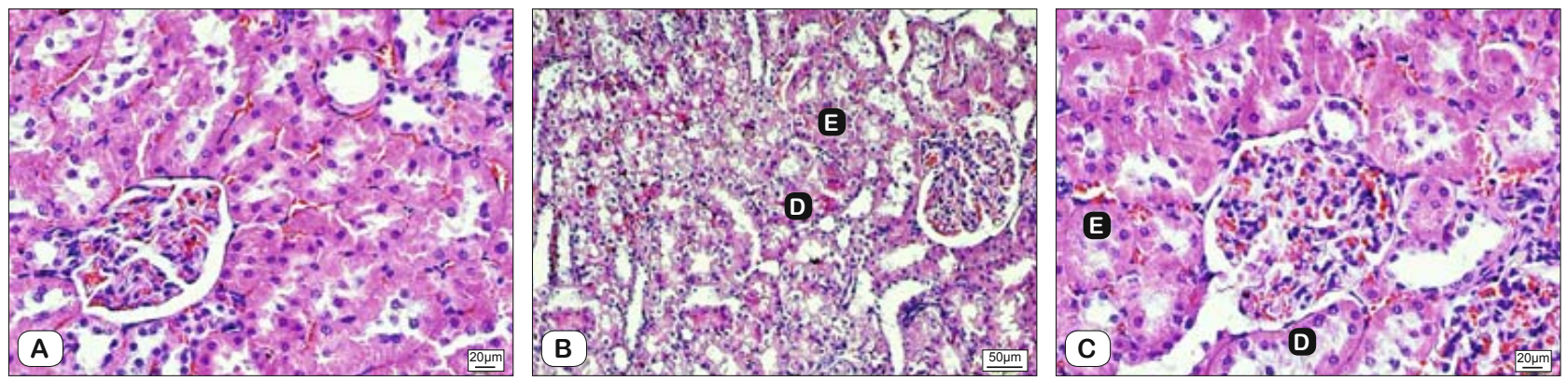

Fig. 1. Histopathologic examination of kidney tissue by light microscopy. A - control group, B - I/R applied group, C - I/R+TPM applied group, D - degenerative cell, E - edema, H\&E stain.
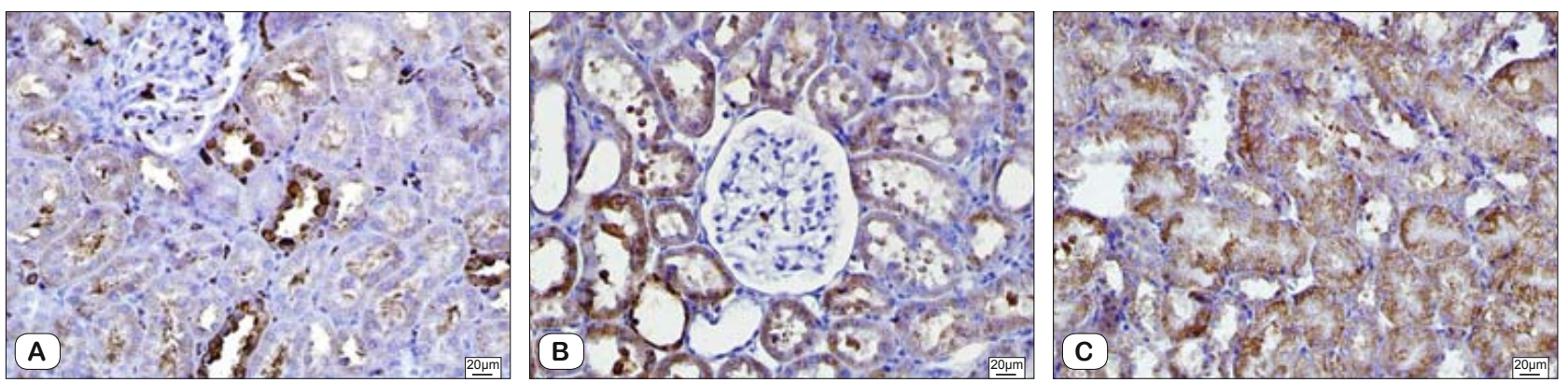

Fig. 2. Histopathologic examination of kidney tissue stained by immunoperoxidase method by light microscopy. A - control group, B - I/R applied group, C - I/R+TPM applied group, Immunoperoxidase stained Anti-Carbonic Anhydrase II antibody.
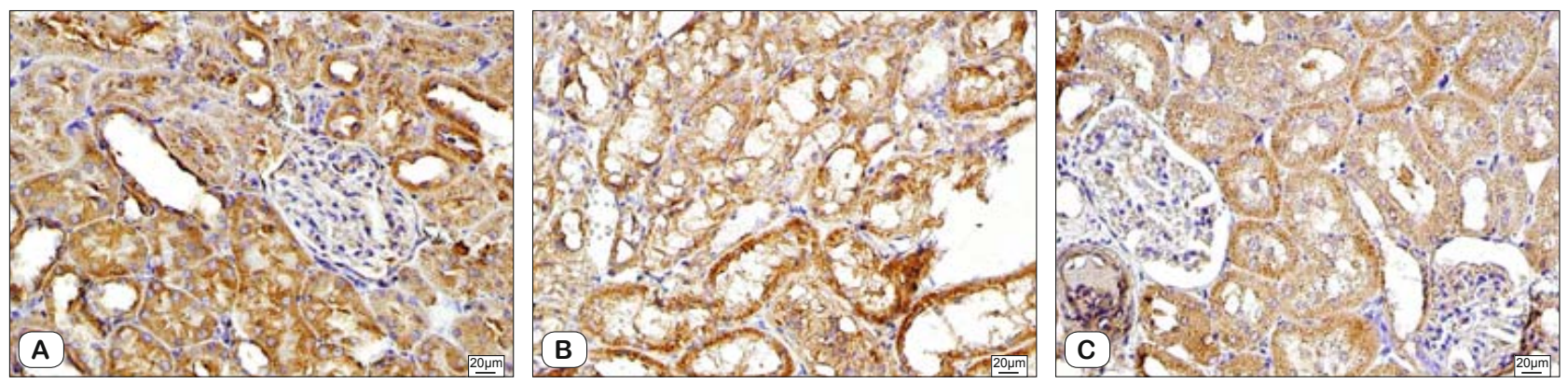

Fig. 3. Histopathologic evaluation of kidney tissue stained by immunoperoxidase method by light microscopy. A - control group, B - I/R applied group, $\mathrm{C}-\mathrm{I} / \mathrm{R}+\mathrm{TPM}$ applied group, Immunoperoxidase stained Anti-TNF- $\alpha$ antibody.

mg protein, $\mathrm{p}<0.001)$. The I/R group's IL- $1 \beta$ levels $(413.1 \pm 28.8$ $\mathrm{pg} / \mathrm{mg}$ protein) were significantly higher than those of the control $(374.7 \pm 23.7 \mathrm{pg} / \mathrm{mg}$ protein, $\mathrm{p}=0.007)$ and $\mathrm{I} / \mathrm{R}+\mathrm{TPM}$ groups $(377.9 \pm 30.9, \mathrm{p}=0.010 \mathrm{pg} / \mathrm{mg}$ protein $)$.

\section{Histologic parameters}

\section{Parameters of (H\&E)}

No textural or cellular deformity was found in the histopathological examination of the control group's kidneys (Fig. 1A).

In I/R animal group's kidneys which was related to edema in both proximal and distal tubules secondary to dilatation, edema, and fluid accumulation in the lumen. In the acute phase of reperfusion, vasoconstriction and an increase in the number of leukocytes were observed in the medulla and cortex border. The lumens of distal tubules were quite enlarged with tubular deformities related to epithelial loss (Fig. 1B).

In I/R+TPM animal group was showed less tissue and cellular deformity than in the I/R group. Even though the dilatations of distal tubules were decreased, they were similar to the control group. In the cells of the proximal tubules, while sporadic degeneration was observed, basophilic stains of the nuclei were noted. Even if the edema and epithelial loss of the tubules cells had decreased, they did not completely disappear. Despite a decrease in edema formation due to tubular structure deformation and cellular loss, there was still edema in the lumen (Fig. 1C).

\section{Immunohistochemical parameters}

The CA results are shown in Figure 2, and TNF- $\alpha$ results are shown in Figure 3. All histologic results are shown in Table 1.

\section{Discussion}

To our knowledge, the present study is the first one which investigates the effects of TPM on I/R-induced renal injury in a rat 
Tab. 1. Histopathologic examination of renal tissue.

\begin{tabular}{|c|c|c|c|c|c|}
\hline Groups & $\begin{array}{c}\text { Cell loss } \\
\text { mean } \pm \text { SD }\end{array}$ & $\begin{array}{c}\text { Edema } \\
\text { mean } \pm \text { SD }\end{array}$ & $\begin{array}{l}\text { Tubular deformation } \\
\text { mean } \pm \text { SD }\end{array}$ & $\begin{array}{c}\text { Anti-CA II } \\
\text { mean } \pm \text { SD }\end{array}$ & $\begin{array}{c}\text { Anti-TNF- } \alpha \\
\text { mean } \pm \text { SD }\end{array}$ \\
\hline Control & $0 \pm 0$ & $0 \pm 0$ & $0 \pm 0$ & $1.2 \pm 0.5$ & $2.8 \pm 0.4$ \\
\hline $\mathrm{I} / \mathrm{R}$ & $3.2 \pm 0.4^{*, \pi}$ & $3.3 \pm 0.5^{*, \uparrow, \mathrm{W}}$ & $3.9 \pm 0.3^{*}$ & $3.3 \pm 0.5^{*, x}$ & $3.4 \pm 0.5^{¥, \beta}$ \\
\hline I/R+TPM & $2.0 \pm 0.5^{*}$ & $2.1 \pm 0.7^{*}$ & $1.2 \pm 0.4^{*}$ & $2.7 \pm 0.4 *$ & $2.4 \pm 0.5$ \\
\hline
\end{tabular}

model. Pretreatment with TPM prevents renal dysfunction, attenuates renal tubular damage, and reduces the inflammatory response at the early stage of renal $\mathrm{I} / \mathrm{R}$, suggesting that TPM was able to protect against renal injury induced by $\mathrm{I} / \mathrm{R}$ in rats.

Acute kidney injury due to $\mathrm{I} / \mathrm{R}$ is characterized by vasoconstriction, oxidative stress, apoptosis, and inflammation (20). Renal tissue damage starts immediately after the onset of ischemia due to a dramatic decrease in oxygen and nutrition. To restore renal blood perfusion as soon as possible, it is critical to decrease renal injury. However, many animal and clinical studies have shown that subsequent reperfusion worsens cell metabolic disorders, leading to additional damages in renal structure and function $(21,22,23)$. Many mechanisms are included in renal $\mathrm{I} / \mathrm{R}$ injury such as the infiltration of inflammatory cells; the generation of inflammatory factors like cytokines, chemokines and, other pro-inflammatory mediators; and the accumulation of ROS (24,2 5). It has been reported that $\mathrm{I} / \mathrm{R}$ leads to tubular dilatation, congestion, brush border loss, and epithelial cell necrosis that aggravates renal structural damages by ROS (26). Tubular cell injury as well as diffuse endothelial cell damage has been demonstrated in I/R and both tubular and endothelial cells contribute to the inflammatory process. Inflammation has become recognized as a critical component of $\mathrm{I} / \mathrm{R}$ injury $(27,28)$.

It has been shown that increased TNF- $\alpha$ and IL- $1 \beta$ levels are markers for apoptosis (29). Elevations of these cytokine levels activate $\mathrm{NF}-\kappa \mathrm{B}$, which stimulates nuclear receptors, leading to greater release of these cytokines and more cellular damage. Protracted or excessive endoplasmic reticulum (ER) stress and pro-inflammatory cytokines trigger renal cell death through the "mitochondrial" or intrinsic pathway of apoptosis (30). A previous study conducted on the protective effect of TPM after cerebral I/R injury has shown marked suppression of neuronal cell death in the hippocampal CA1 area of ischemic gerbils after treatment with TPM (31). In our study, the I/R group's TNF- $\alpha$ and IL- $1 \beta$ levels were significantly higher than those of the control group. The levels of TNF- $\alpha$ and IL-1 $\beta$ of the TPM-treated group were significantly lower than the I/R group and similar to the control group. TNF- $\alpha$ activity was immunohistochemically shown to be low in the I/R+TPM group. TPM as an inhibitor of TNF- $\alpha$ and an antioxidant during I/R injury suppresses the release of cytokines and decreases/improves renal damage.

CA is a widespread metaloenzyme that catalyzes the biochemical reaction of $\mathrm{CO}_{2}$ hydration to the bicarbonate ion and proton (32). This reaction makes CA engage in various physiological processes such as $\mathrm{pH}$ and $\mathrm{CO}_{2}$ homeostasis, electrolyte secretion, gluconeogenesis, lipogenesis, ureagenesis and bone resorption, calcification, and tumorigenicity (33). CA II, which is synthesized by renal tubules, has a role in $\mathrm{Na}^{+}$and $\mathrm{H}_{2} \mathrm{O}$ reabsorption (17). In a previous study, CA III overexpressing cells were used as a mod- el to test the role of CA III in a cellular defense system against oxidative stress (34). However, CA II did not seem to have this capacity; the increased level of CAII may be harmful (17). It is present in most tissues with high CA II enzyme activity, including gastric cancer, liver and bile duct cancer, colon cancer, renal cell carcinoma, melanoma, brain astrocytic tumors, pancreatitis cells in mice, and cardiomyocyte hypertrophy (35). Cancer cells have a higher replication rate than normal cells and thus require a high flux of bicarbonate into these metabolic pathways. Providing that bicarbonate is a substrate for carbonic anhydrase, isoforms play an important role in tumor cell growth (36). Inhibition of CA II by acetazolamide has been shown in vitro to strongly reduce the invasiveness of some renal cancer cell lines (37). On the other hand, $\mathrm{H}_{2} \mathrm{O}_{2}$ is a major factor that induces apoptosis. In previous experiments, $\mathrm{H}_{2} \mathrm{O}_{2}$ induced cellular apoptosis (38). Most studies describing the role of $\mathrm{CO}_{2} / \mathrm{HCO}_{3}{ }^{-}$in biological oxidations have been conducted in vitro and less commonly in vivo systems to which oxidants were added exogenously promoting overt oxidative stress followed by an evaluation of the effects of $\mathrm{HCO}_{3}{ }^{-}$. $\mathrm{CO}_{2} /$ $\mathrm{HCO}_{3}^{-}$levels affect tissues under physiologically suitable conditions, providing indirect evidence of carbonate radicals' participation in biologically relevant processes $(39,40)$. Previous study found that although various concentrations of $\mathrm{CO}_{2} / \mathrm{HCO}_{3}{ }^{-}$have no effect under basal conditions, when I/R was applied in the presence of higher $\mathrm{CO}_{2} / \mathrm{HCO}_{3}^{-}$, it resulted in greater functional loss associated with higher oxidative damage in all models (41). TPM inhibits CA enzymes. Many studies have shown that TPM lowers serum $\mathrm{HCO}_{3}^{-}$levels (42). In our study, the high level of CA II in the $\mathrm{I} / \mathrm{R}$ group indirectly indicates the expression of high levels of bicarbonate during I/R. Excessive bicarbonate may lead to activation of the apoptosis pathway related to increased levels of free radicals and oxidative stress. The TPM-treated group's CA II activity was higher than the control group. However, it was lower than that of the I/R group. TPM partially inhibited CA II. TPM has not been reported in the literature on the experimental abdominal aorta $\mathrm{I} / \mathrm{R}$ model yet, as higher dosages may be needed to inhibit CA II.

In conclusion, TPM significantly improved renal function recovery after I/R injury and effectively inhibited the induction of pro-inflammatory mediators by suppressing the NF- $\mathrm{BB}$ signaling pathway. Our results substantiate TPM as a novel therapeutic agent for the treatment of acute ischemic renal failure.

\section{References}

1. Mosquera VX, Marini M, Cao I et al. Traumatic aortic injuries associated with major visceral vascular injuries in major blunt trauma patients. World J Surg 2012; 36 (7): 1571-1580. 
2. Oyar EÖ, Kiriş I, Gülmen S et al. The protective effect of adrenomedullin on renal injury, in a model of abdominal aorta cross-clamping. Thorac Cardiovasc Surg 2012; 60 (1): 5-10.

3. Lorenzen JM, Batkai S, Thum T. Regulation of cardiac and renalischemiareperfusion injury by microRNAs. Free Radic Biol Med 2013; 64: 78-84

4. Fang F, Liu GC, Zhou $X$ et al. Loss of ACE2 exacerbates murine renal ischemia-reperfusion injury. PLoS One 2013; 8 (8): 71433.

5. Soljancic A, Ruiz AL, Chandrashekar K et al. Protective role of testosterone in ischemia-reperfusion-induced acute kidney injury. Am J Physiol Regul Integr Comp Physiol 2013; 304 (11): 951-958.

6. Hu L, Yang C, Zhao T et al. Erythropoietin ameliorates renal ischemia and reperfusion injury via inhibiting tubulointerstitial inflammation. J Surg Res 2012; 176 (1): 260-266.

7. Wang F, Yu G, Liu SY et al. Hydrogen-rich saline protects against renal ischemia/reperfusion injury in rats. J Surg Res 2011; 167 (2): 339-344.

8. Das J, Sil PC. Taurine ameliorates alloxan-induced diabetic renal injury, oxidative stress-related signaling pathways and apoptosis in rats. Amino Acids 2012; 43 (4): 1509-1523.

9. Sommer BR, Mitchell EL, Wroolie TE. Topiramate: Effects on cognition in patients with epilepsy, migraine headache and obesity. Ther Adv Neurol Disord 2013; 6 (4): 211-227.

10. Moradi S, Kerman SR, Mollabashi M. The effect of topiramate on weight loss in patients with type 2 diabetes. J Res Med Sci 2013; 18 (4): 297-302.

11. El-Abhar HS, Schaalan MF. Topiramate-induced modulation of hepatic molecularmechanisms: an aspect for its anti-insulin resistant effect. PLoS One 2012; 7 (5): 37757.

12. Himmerich $\mathbf{H}$, Bartsch $\mathbf{S}$, Hamer $\mathbf{H}$ et al. Impact of mood stabilizers and antiepileptic drugs on cytokine production in-vitro. J Psychiatr Res 2013; 47 (11): 1751-1759.

13. Nazıroğlu M, Yürekli VA. Effects of antiepileptic drugs on antioxidant and oxidant molecular pathways: focus on trace elements. Cell Mol Neurobiol 2013; 33 (5): 589-599.

14. Di Paola R, Genovese T, Impellizzeri D, Ahmad A, Cuzzocrea S, Esposito $\mathbf{E}$. The renal injury and inflammation caused by ischemia-reperfusion are reduced by genetic inhibition of TNF- $\alpha$ R1: a comparison with infliximab treatment. Eur J Pharmacol 2013; 700 (1-3): 134-146.

15. Sh Ali AA, Al-Mashta SA. Cerebral calcification, osteopetrosis and renal tubular acidosis: is it carbonic anhydrase-II deficiency? Saudi J Kidney Dis Transpl 2013; 24 (3): 561-565.

16. Maryanoff BE, McComsey DF, Costanzo MJ, Hochman C, SmithSwintosky V, Shank RP. Comparison of sulfamate and sulfamide groups for the inhibition of carbonic anhydrase-II by using topiramate as a structural platform. J Med Chem 2005; 48 (6): 1941-1947.

17. Kurt O, Ozden TY, Ozsoy $N$ et al. Influence of vanadium supplementation on oxidative stress factors in the muscle of STZ-diabetic rats. Biometals 2011; 24 (6): 943-949.

18. Armagan A, Kutluhan S, Yilmaz $M$ et al. Topiramate and vitamin e modulate antioxidant enzyme activities, nitric oxide and lipid peroxidation levels in pentylenetetrazol-induced nephrotoxicity in rats. Basic Clin Pharmacol Toxicol 2008; 103 (2): 166-170.

19. Oyar EÖ, Kiriş I, Gülmen S et al. Adrenomedullin attenuates aortic crossclamping-induced myocardial injury in rats. Am J Surg 2011; 201 (2): 226-232.

20. Chu C, He W, Kuang Y, Ren K, Gou X. Celastrol protects kidney against ischemia-reperfusion-induced injury in rats. J Surg Res. 2013; 186 (1): 398-407.

21. Moeini M, Nematbakhsh M, Fazilati M et al. Protective role of recombinant human erythropoietin in kidney and lung injury following renal bilateral ischemia-reperfusion in rat model. Int J Prev Med 2013; 4 (6): 648-655.

22. Yoshida T, Kumagai H, Kohsaka T, Ikegaya N. Relaxin protects againstrenal ischemia-reperfusion injury. Am J Physiol Renal Physiol 2013;305 (8): 1169-1176.
23. Yu W, Sheng M, Xu R et al. Berberine protects human renal proximal tubular cells from hypoxia/reoxygenation injury via inhibiting endoplasmic reticulum and mitochondrial stress pathways. J Transl Med 2013; 11: 24.

24. dos Santos EB, Koff WJ, Grezzana Filho Tde J et al. Oxidative stress evaluation of ischemia and reperfusion in kidneys under various degrees of hypothermia in rats. Acta Cir Bras 2013; 28 (8): 568-573.

25. Sharfuddin AA, Sandoval RM, Berg DT et al. Soluble thrombomodulin protects ischemic kidneys. J Am Soc Nephrol 2009; 20 (3): 524-534.

26. Changizi Ashtiyani S, Zohrabi M, Hassanpoor A, Hosseini N, Hajihashemi S. Oral administration of the aqueous extract of Rosmarinus officinalis in rats before renal reperfusion injury. Iran J Kidney Dis 2013; 7 (5): 367-375.

27. Ayupova DA, Singh M, Leonard EC, Basile DP, Lee BS. Expression of the RNA-stabilizing protein HuR in ischemia-reperfusion injury of rat kidney. Am J Physiol Renal Physiol 2009; 297 (1): 95-105.

28. Han KH, Lee UY, Jang YS et al. Differential regulation of B/K protein expression in proximal and distal tubules of rat kidneys with ischemia-reperfusion injury. Am J Physiol Renal Physiol 2007; 292 (1): 100-106.

29. Awad AS, El-Sharif AA. Curcumin immune-mediated and anti-apoptotic mechanisms protect against renal ischemia/reperfusion and distant organ induced injuries. Int Immunopharmacol 2011; 11 (8): 992-996.

30. Tsuda H, Kawada N, Kaimori JY et al. Febuxostat suppressed renal ischemia-reperfusion injury via reduced oxidative stress. Biochem Biophys Res Commun 2012; 427 (2): 266-272.

31. Mao X, Ji C, Sun C et al. Topiramate attenuates cerebral ischemia/reperfusion injury in gerbils via activating GABAergic signaling and inhibiting astrogliosis. Neurochem Int 2012; 60 (1): 39-46.

32. Supuran CT. Bacterial carbonic anhydrases as drug targets: toward novel antibiotics? Front Pharmacol 2011; 2: 34.

33. Neri D, Supuran CT. Interfering with $\mathrm{pH}$ regulation in tumours as a therapeutic strategy. Nat Rev Drug Discov 2011; 10 (10): 767-777.

34. Zimmerman UJ, Wang $P$, Zhang $X$, Bogdanovich S, Forster R. Antioxidative response of carbonic anhydrase III in skeletal muscle. IUBMB Life 2004; 56 (6): 343-347.

35. Liu LC, Xu WT, Wu X, Zhao P, Lv YL, Chen L. Overexpression of carbonic anhydrase II and $\mathrm{Ki}-67$ proteins in prognosis of gastrointestinal stromal tumors. World J Gastroenterol 2013; 19 (16): 2473-2480.

36. Lankat-Buttgereit B, Göke R. The tumour suppressor Pdcd4: recent advances in the elucidation of function and regulation. Biol Cell 2009; 101 (6): 309-317.

37. Parkkila S, Rajaniemi H, Parkkila AK et al. Carbonic anhydrase inhibitor suppresses invasion of renal cancer cells in vitro. Proc Natl Acad Sci USA 2000; 97 (5): 2220-2224.

38. Raisanen SR, Lehenkari P, Tasanen M, Rahkila P, Harkönen PL, Vaananen HK. Carbonic anhydrase III protects cells from hydrogen peroxideinduced apoptosis. FASEB J 1999; 13 (3): 513-522.

39. Medinas DB, Cerchiaro G, Trindade DF, Augusto O. The carbonate radical and related oxidants derived from bicarbonate buffer. IUBMB Life 2007; 59 (4-5): 255-262.

40. Andrekopoulos C, Zhang H, Joseph J, Kalivendi S, Kalyanaraman B. Bicarbonateenhances alpha-synucleinoligomerization and nitration: intermediacy of carbonateradical anion and nitrogen dioxide radical. Biochem $\mathbf{J}$ 2004; 378 (Pt 2): 435-447.

41. Queliconi BB,MarazziTB,VazSMetal.Bicarbonatemodulates oxidativeand functional damage in ischemia-reperfusion. Free Radic Biol Med 2013; 55: 46-53.

42. Mirza NS, Alfirevic A, Jorgensen A, Marson AG, Pirmohamed M. Metabolic acidosis with topiramate and zonisamide: an assessment of its severity and predictors. Pharmacogenet Genomics 2011; 21 (5): 297-302.

Received January 2, 2014. Accepted January 17, 2014. 